\title{
ARTICLE
}

\section{Phytochemical analysis, cytotoxicity and antioxidant activity of cuckoo pint (Arum maculatum) leaf extract}

\author{
Hanady SA Al-Shmgani' ${ }^{1}$ Zahraa Hussein M Kadri', Mohammad MF Al-Halbosiy'², Yaser \\ Hassan Dewir ${ }^{3,4^{*}}$ \\ 'Biology Department, College of Education for Pure Science/Ibn al-Haitham, University of Baghdad, Baghdad, Iraq \\ ${ }^{2}$ Biotechnology Research Center, Al-Nahrain University, Baghdad, Iraq \\ ${ }^{3}$ Plant Production Department, College of Food and Agriculture Sciences, King Saud University, Riyadh 11451, \\ Saudi Arabia \\ ${ }^{4}$ Department of Horticulture, Faculty of Agriculture, Kafrelsheikh University, Kafr El-Sheikh 33516, Egypt
}

\begin{abstract}
Arum maculatum is traditionally used for the control of many diseases and illnesses such as kidney pain, liver injury, hemorrhoids. However, the detailed biomedical knowledge about this species is still lacking. This study reports on the bioactive components and the possible mechanisms underlying the antioxidant, anti-inflammatory and cytotoxic activity of $A$. maculatum leaf extract. Gas chromatography-mass spectrometry (GC-MS) was used for phytochemical analysis. Assay of 3-(4,5-dimethylthiazol-2-yl)-2,5diphenyltetrazolium bromide ) (MTT) was used to determine the cytotoxicity in the murine cell line L20B upon exposure to different extract concentrations for $24 \mathrm{~h}$. Enzyme-linked immunosorbent assay (ELISA) was used to detect pro-inflammatory cytokines and tumor necrosis factor-a (TNF-a). GC-MS analysis identified the presence of important phytochemical components, e.g., 9-octadecenoic acid, methyl ester, (E), hexadecanoic acid, methyl ester, followed by benzenepropanoic acid, 3,5-bis(1,1-dimethylethyl)-4-hydroxy-, methyl ester (17.74\%), heptadecanoic acid, 16-methyl-, methyl ester and dibutyl phthalate. The results indicated a significant dose-dependent decrease in L20B cell growth at a dose of $400 \mu \mathrm{g} / \mathrm{ml}\left(\mathrm{IC}_{50}\right)$ that is associated with a significant 2,2-diphenyl-1-picrylhydrazyl (DPPH) scavenging activity. The results suggested that the aqueous extract of $A$. maculatum leaves have potent antioxidant activity and cytotoxicity against L20B cell line with potential pro-inflammatory activity.

Acta Biol Szeged 63(2):119-124 (2019)
\end{abstract}

\section{KEY WORDS}

Arum maculatum $\mathrm{DPPH}$

GC-MS analysis L20B cell line MTT

\section{Introduction}

A very large number of individuals around the world still rely on traditional medicine for the treatment of various acute and chronic diseases. Even in countries where the modern medicine is very advanced, these herbal extracts, syrups, essential oils and other formulations are sold in pharmacies and supermarkets. Botanical supplements are believed to be safe as there are no or minimal side-effects. Moreover, using herbal medicines is advantageous due to the occurrence of several biologically active compounds which in certain cases may act synergistically to deliver an effective curing power that cannot be attained by any one component in the natural mixture. On the other hand, they could also be harmful because of the possible presence of toxic components (Ekor 2014).

The genus Arum, belonging to the Araceae family, has a long history of traditional medicinal uses in the
Middle East, southern Europe and northern Africa. In folk medicine, Arum species such as A. dioscorides (AfifiYazar et al. 2011) and A. palaestinum (Afifi-Yazar et al. 2011; Zaid et al. 2012; Naseef et al. 2017) have been used for the treatment of cancer. Cuckoo pint (A. maculatum) is a woodland plant that grows in the northern region of Iraq where it is commonly known as 'kardi'. Cuckoo pint leaves are the edible parts consumed by the local population after removing the toxic constituents by cooking. Toxicity of $A$. maculatum is attributable to the presence of toxic volatiles, especially amines, oxalates, cyano compounds as well as contents such as alkaloids and saponins (Azab 2017).

The raw plant is not edible due to its toxic and allergenic properties. It has been reported to cause irritation to skin, mouth, tongue, and throat, resulting in throat swelling, difficulty in breathing, burning pain, and stomach ache (Robertson 2009). However, its therapeutic importance for many diseases, including kidney 
and liver injuries, hemorrhoids and as a pain reliever has been reported (Abbasi et al. 2014; Kochmarov et al. 2015). Mice orally treated with $A$. maculatum methanolic extract showed different histological and antioxidant activity effects in the liver (Kadri et al. 2016). Other studies have shown antimicrobial and antifungal activities of this plant extract against a wide range of Gram-positive, Gramnegative bacteria and fungi (Safari et al. 2014; Çolak et al. 2009). The pro-inflammatory activity of monocot lectin isolated from A. maculatum has been reported to increase neutrophil migration (Alencar et al. 2005). The antitumor activity of $A$. palaestinum on different human cancer cells has been investigated by Farid et al. (2015), where significant anti-proliferative activity was reported. TNF- $\alpha$ initiate inflammation, either local or systemic, via stimulation of cytokines such as interleukin-1 $\beta$ (IL-1 $\beta$ ) and IL-6. Other roles are the signal suppression of T-cell and the inhibition of antigen production by dendritic cells (O'Shea et al. 2002). IL-1 $\beta$ induces both local and systemic signs of inflammation. It also promotes the production of various enzymes, for example, cyclooxygenase type 2 , adhesion molecules and importantly other cytokines and chemokines of pathogenic importance in some diseases (Dinarello et al. 2009). The present study aimed to investigate the active compounds in the aqueous extracts of $A$. maculatum leaves as well as their antioxidant, antiinflammatory and cytotoxic effects.

\section{Materials and Methods}

\section{Chemicals and reagents}

Cell culture reagents were purchased from Lonza (Slough, Berkshire, UK). Culture plates were obtained from Becton Dickinson. Roswell Park Memorial Institute (RPMI) 1640 medium was purchased from Gibco (Paisley, UK). All other reagents and chemicals [(4-(2-hydroxyethyl)1-piperazineethanesulfonic acid (HEPES), Fetal bovine serum (FBS) trypsin, DPPH and MTT] were of analytical grade and purchased from Sigma-Aldrich (St. Louis, MO, USA). Mouse IL-1 $\beta$ and TNF- $\alpha$ were obtained from Pierce Endogen (Rockford, IL, USA).

\section{Plant collection and extract preparation}

A. maculatum leaves were obtained from a local market in the Kurdistan region located north of Iraq and was identified by an eminent plant taxonomist at Baghdad University. Voucher specimens were deposited at the Herbarium of Bakrajo Agricultural Technical Institute (Sulaimani Polytechnic University, Kurdistan, Iraq). Leaves were air dried at room temperature, and then grounded into powder. The aqueous extraction method was selected to prepare A. maculatum extract because it is a commonly used method in folk medicine. The extract was prepared as follows (Taskeen et al. 2009): $50 \mathrm{~g}$ of powdered dried leaf powder was suspended in $500 \mathrm{ml}$ of distilled water in conical flasks and stirred for $6 \mathrm{~h}$ using a magnetic stirrer. The extracts were filtrated using filter paper (Whatman No. 1) and centrifuged at $3000 \mathrm{rpm}$ for $10 \mathrm{~min}$. The supernatants were then transferred and dried under reduced pressure using a rotary evaporator and were kept at $4{ }^{\circ} \mathrm{C}$ for further analysis and experiments.

\section{GC-MS analysis and identification of phytochemical components}

The GC-MS analysis of aqueous cuckoo pint (A. maculatum; ' $k a r d i$ ') extract was performed using a Clarus 500/580 Perkin Elmer GC (Connecticut, USA), including a AOC20i auto-sampler, and equipped with a fused silica capillary column Elite-1 (100\% methyl polysiloxane; $30 \mathrm{~m} \times 0.25$ $\mathrm{mm}, 0.25 \mu \mathrm{m})$. Helium (99.99\%) was used as a carrier gas at a constant flow rate of $1 \mathrm{ml} / \mathrm{min} .0 .5 \mu \mathrm{l}$ samples were injected at a split ratio (1:10). Injector temperature was $280^{\circ} \mathrm{C}$. Oven temperature was programmed to automatically increase at a rate of $10^{\circ} \mathrm{C} / \mathrm{min}$ from $110^{\circ} \mathrm{C}$ up to 200 ${ }^{\circ} \mathrm{C}$, then at $5{ }^{\circ} \mathrm{C} / \mathrm{min}$ further up to $280^{\circ} \mathrm{C}(10 \mathrm{~min})$. Mass scans were taken at electron energy $70 \mathrm{eV}(0.5 \mathrm{sec}$ scan interval) and in the range of $40-450 \mathrm{Da}$; with a total run time of $36 \mathrm{~min}$. Analysis of mass spectrum of GC-MS was done using the database of the National Institute Standard and Technology (NIST). The mass spectrum of the unknown components was compared with the spectrum of the components stored in the NIST library (Nezhadali et al. 2010; Sathyaprabha et al. 2011).

\section{Antioxidant activity measurement}

The antioxidant activity was determined using 2,2-diphenyl-1-picrylhydrazyl (DPPH) according to MimicaDukic et al. (2003). The DPPH assay has been widely used to detect the scavenging activities of plant extracts. The principle of the assay is based on reduction of DPPH via hydrogen donation from antioxidant by which the color change can be spectrophotometrically recorded. Briefly, $1 \mathrm{ml}$ of the samples was mixed with an equal volume of the DPPH solution $(60 \mu \mathrm{M})$. After $30 \mathrm{~min}$ incubation at $37^{\circ} \mathrm{C}$ in darkness, the absorbance was recorded at 517 nm spectrophotometrically (Perkin-Elmer Lambda 25, Germany). L-ascorbic acid was used as a positive control and measurements were carried out in triplicate. Inhibition of free radicals by DPPH was calculated by the following equation:

$$
\text { DPPH scavenging activity }(\%)=\text { Ac-As } / \text { Ac } \times 100
$$

Where, $A c=$ control absorbance and As = sample absorbance 


\section{Cell culture}

The murine cell line L20B was provided by the Center of Biotechnology at Al-Nahrain University (Baghdad, Iraq). L20B cell line is derived from mouse cells (fibroblasts) and has been found to express the human poliovirus receptor (Pipkin et al. 1993). RPMI-1640 medium containing $10 \%$ fetal bovine serum (FBS), $1 \%$ antibiotic (containing $10000 \mathrm{U} / \mathrm{ml}$ penicillin $\mathrm{G}, 10 \mathrm{mg} / \mathrm{ml}$ streptomycin and $25 \mu \mathrm{g} / \mathrm{ml}$ amphotericin B) was used for cell culture and maintenance. Cells were incubated at $37^{\circ} \mathrm{C}$ in humidified $5 \% \mathrm{CO}_{2}$ and cultured to $2.5 \times 10^{5} \mathrm{cells} / \mathrm{ml}$ concentration.

\section{Measurement of cell viability}

The colorimetric cell viability MTT assay was carried out as described before (Nouri et al. 2015). Cells were seeded in 96-well plates at a concentration of $1 \times 10^{5} \mathrm{cell} /$ $\mathrm{ml}$. After $48 \mathrm{~h}$ of incubation, $100 \mu \mathrm{l}$ of plant extracts at concentrations of $0.4,4,40$ and $400 \mu \mathrm{g} / \mathrm{ml}$ were added to each well followed by an incubation period of $24 \mathrm{~h}$. After the incubation, $10 \mu \mathrm{l}$ of MTT solution $(5 \mathrm{mg} / \mathrm{ml})$ was added to each well and the plates were further incubated at 37 ${ }^{\circ} \mathrm{C}$ for $4 \mathrm{~h}$. Finally, $50 \mu \mathrm{l}$ of dimethyl sulfoxide (DMSO) was added to each well and incubated for $10 \mathrm{~min}$. L20B cells cultured in medium without $A$. maculatum extract served as the control. The absorbance was measured at $620 \mathrm{~nm}$ using a microplate reader (VersaMax, Molecular Devices, Sunnyvale, CA). Percent of inhibition ratio was calculated according to the following formula:

$\mathrm{GI} \%=\frac{(\mathrm{OD} \text { of control wells }- \text { OD of test wells })}{\text { OD of control wells }} \times 100$

Where GI = growth index and $\mathrm{OD}=$ optical density.

\section{Detection of pro-inflammatory cytokines by enzyme- linked immunosorbent assay (ELISA)}

Protein levels of TNF- $\alpha$ and IL-1 $\beta$ in the serum were measured using an ELISA kit (Pierce Endogen, Rockford, IL, USA) according to the manufacturer instructions. Briefly, $50 \mu \mathrm{l} /$ well of samples (treated mice with 50 and $100 \mu \mathrm{g} /$ $\mathrm{ml}$ and control mice which received normal saline solution of $0.9 \% \mathrm{NaCl}$ ) was added to the anti-mouse TNF- $\alpha$ and IL-1 $\beta$-pre-coated 96 -well plates. After washing with phosphate buffered saline (PBS, containing $0.05 \%$ Triton $\mathrm{X}-100)$, the detection antibodies $(0.5 \mu \mathrm{g} / \mathrm{ml})$ were dissolved in $2 \%$ bovine serum albumin (BSA) in PBS and then added to the plates before incubation for $4 \mathrm{~h}$ at room temperature. After washing, $50 \mu \mathrm{l}$ of conjugate streptavidin-horseradish peroxidase (HRP) dissolved in 2\% BSA (in PBS) (1:250) was added to each well. After washing with the buffer, $100 \mu \mathrm{l}$ of chromogenic substrate tetramethylbenzidine (TMB) was added to each well before incubation for 15 min at room temperature to allow color development.
To stop the reaction, the HRP was denatured by adding $1 \mathrm{M}$ sulfuric acid $(50 \mu \mathrm{l} /$ well) resulting in a color change to yellow. Absorbance was read at $450 \mathrm{~nm}$ using a plate reader (VersaMax, Molecular Devices, Sunnyvale, CA, USA) equipped with SoftMax Pro software version 5.4. The cytokine concentrations were determined by comparison with the values for standard recombinant human cytokines $(0-5 \mathrm{ng} / \mathrm{ml})$ and all samples were analyzed in triplicate.

\section{Statistical analysis}

Statistical analysis was performed using SPSS software version 16.0. All results are presented as means \pm standard error. Significance was calculated using analysis of variance (ANOVA) and Fisher Least Significant Difference (LSD) test.

\section{Results and Discussion}

\section{GC-MS analysis}

GC-MS analysis of the leaf extracts showed the presence of major components (peak area $>1 \%$ ). The major compounds identified are: 9-octadecenoic acid, methyl ester, (E) (24.76\%), hexadecanoic acid, methyl ester (22.45\%), followed by benzenepropanoic acid, 3,5-bis(1,1dimethylethyl)-4-hydroxy-, methyl ester (17.74\%). These constituents have been investigated for their biological and therapeutic properties, including the anti-inflammatory (Othman et al. 2015), antioxidant (Pinto et al. 2017), antibacterial and antifungal activities (Agoramoorthy et al. 2007). Previous investigation has shown that palmitic acid induces apoptosis in the human leukemic cell line and demonstrated in vivo antitumor activity in mice (Harada et al. 2002). Our results are supported by those of a previous report (Kianinia and Farjam 2018) of the essential oil of Iranian A. maculatum extracts, mainly consisting of palmitic acid, phytol, methyl 9,12,15-octadecatrienoate and methyl linolenate.

\section{Antioxidant activity}

The aqueous extract was tested for its antioxidant activity at concentrations of 100,150,200, and $250 \mu \mathrm{g} / \mathrm{ml}$ using DPPH. Results showed that the extracts showed a significantly higher and concentration-dependent radical scavenging activity up to $200 \mu \mathrm{g} / \mathrm{ml}$, as compared with the positive control (L-ascorbic acid). Higher activity $(P \leq$ $0.01)$ was observed at $250 \mu \mathrm{g} / \mathrm{ml}$ while the lowest activity was observed at $100 \mu \mathrm{g} / \mathrm{ml}(P \leq 0.05)$ compared with the ascorbic acid control (Fig. 1).

The antioxidant activity of phenols and flavonoids has been attributed to their redox activities, allowing them to act as reducing agents and free radical scaven- 


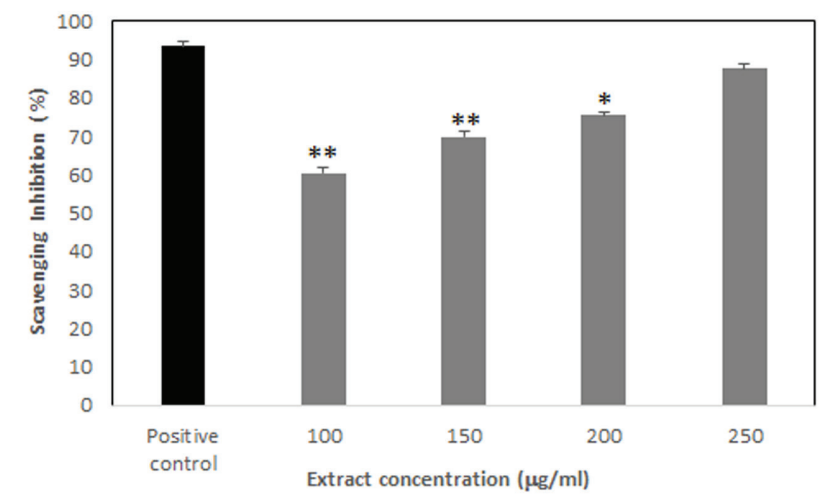

Figure 1. DPPH free radical scavenging activity of $A$. maculatum leaf extract measured at $517 \mathrm{~nm}$. Values presented are means $\pm \mathrm{SE}(\mathrm{n}=$ 3). Stars mean significant difference at $P \leq 0.05\left(^{(*)}\right.$ and $P \leq 0.01\left(^{(*}\right)$, respectively, as compared to positive control (L-ascorbic acid).

gers. The observed DPPH scavenging activities indicate an antioxidant protective role against oxidative stress, which is implicated in several diseases. The DPPH assay has been widely used to detect the radical scavenging activity of extracts of several medicinal plant species, including Panax ginseng (Ali et al. 2006), Echinacea purpurea (Paek et al. 2009), Withania somnifera (Dewir et al. 2010) and Albizia odoratissima (Banothu et al. 2017). The results reported herein suggest that $A$. maculatum leaf extracts contain hydrogen donating compounds that can eliminate free radicals and therefore could explain their therapeutic application for different pathological injuries caused by oxidation.

\section{Cell viability}

Our results showed that treatment with $A$. maculatum extract significantly $(P \leq 0.01)$ inhibited cell growth as compared to control cultures (Fig. 2). The highest inhibition $(69 \% \pm 0.024)$ was recorded at $400 \mu \mathrm{g} / \mathrm{ml}$ and it decreased when extract concentration was reduced, reaching only $45 \% \pm 0.020$ cell growth inhibition at $0.4 \mu \mathrm{g} / \mathrm{ml}$. Therefore, the suppression of LB20 cell proliferation was concentration dependent. These results might be due to the presence of flavonoids, glycosides, polyphenols and saponins which act as active agents against cell death. It has been previously reported that fatty acids may play a role in triggering apoptosis associated with trauma in the central nervous system (CNS) and peripheral nervous system (PNS) (Ulloth et al. 2003). Our results indicated that the major compounds present in A. maculatum extract are fatty acids, including hexadecanoic acid, palmitic acid (a saturated fatty acid), and 9-octadecenoic acid, methyl ester, (E) (elaidic acid), an unsaturated fatty acid.

Generally, fatty acids and their methyl ester derivatives are biologically active compounds with antioxidant, anticancer and antihistaminic properties (Melariri et al.

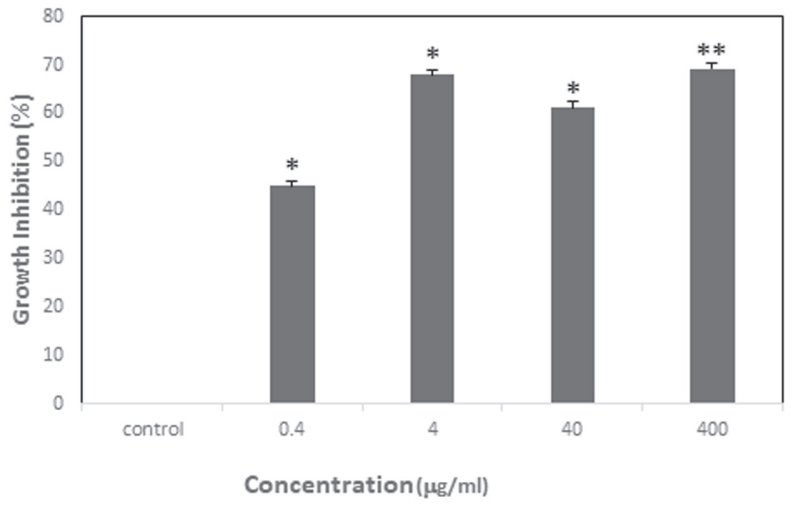

Figure 2. Growth inhibition of L20B cell lines treated with different concentrations of $A$. maculatum leaf extract using MTT assay after 24 h of treatment. Values presented are means $\pm S E(n=3)$. Stars mean significant difference at $P \leq 0.05\left(^{*}\right)$ and $P \leq 0.01\left(^{* *}\right)$, respectively, as compared to control.

2012). Palmitic acid has been reported earlier as a potential anticancer drug (Harada et al. 2002) as significant loss of viability of nerve growth factor (NGF)-differentiated PC12 cells was observed after $24 \mathrm{~h}$ treatment with stearic and

TNF- $\alpha$

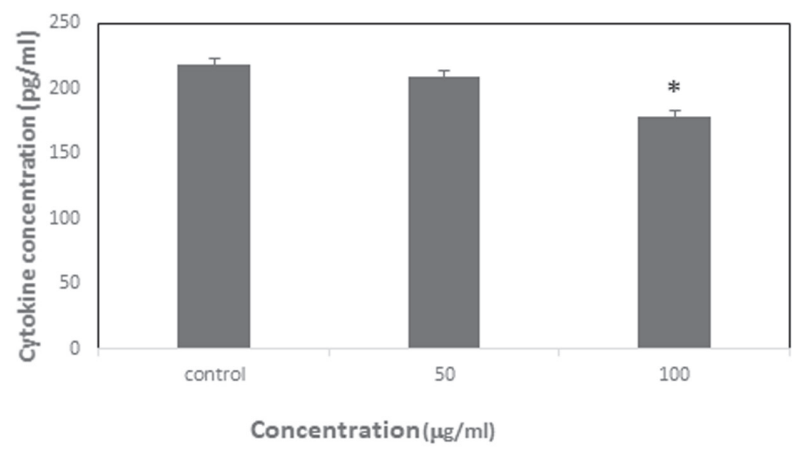

$\mathrm{IL}-1 \beta$

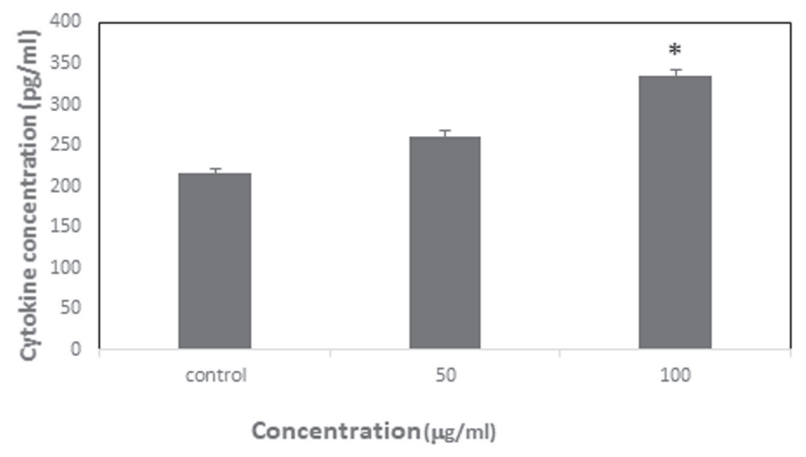

Figure 3. Concentrations of pro-inflammatory cytokines TNF- $\alpha$ and IL$1 \beta$ determined by ELISA from mice serum in response to treatment with different concentrations of $A$. maculatum leaf extract. Values presented are means $\pm \mathrm{SE}(\mathrm{n}=3)$. Stars means significantly different at $P \leq 0.01$ $\left.{ }^{*}\right)$ as compared to control. 
palmitic acids. Additionally, a fortified aqueous extract of Arum palaestinum contained high levels of isovanillin, linolenic acid and $\beta$-sitosterol which significantly reduced the number of live prostate cancer cells line in a dosedependent manner, shifting the percentage of dead cells from $30 \%$ to $55 \%$ at the highest dose (doses of 0.015 to $6.25 \mathrm{mg} / \mathrm{ml}$ ) (Cole et al. 2015).

\section{Determination of pro-inflammatory cytokines}

ELISA showed that the mean concentrations of the two cytokines (IL-1 $\beta$ and TNF- $\alpha$ ) were dose-dependent (Fig. 3). Mice treated with A. maculatum extract at $100 \mathrm{ng} /$ $\mathrm{ml}$ showed significantly $(P \leq 0.05)$ decreased TNF- $\alpha$ cytokine levels, whereas $50 \mathrm{ng} / \mathrm{ml}$ caused no significant reduction. However, treatment with 50 and $100 \mathrm{ng} / \mathrm{ml}$ increased IL-1 $\beta$ level in the blood and significantly higher cytokine levels $(P \leq 0.05)$ were observed with $100 \mathrm{ng} / \mathrm{ml}$, as compared to controls.

A. maculatum agglutinin reportedly shows both dosedependent and independent pro-inflammatory activity, inducing neutrophil migration by the resident cells and in the presence of macrophages, respectively (Alencar et al. 2005). It has been reported that the underlying mechanism of the anti-inflammatory and anti-microbial activities of flavones are due to their ability to regulate the Toll receptor/ NFxB axis which is responsible for the expression of mediator inflammation such as TNF- $\alpha$, IL$1 \beta$ and cyclooxygenase- 2 (Jiang et al. 2016). Gupta et al. (2010) proposed that the small molecules that suppress $\mathrm{NF}-x \mathrm{~B}$ activation might have a prospective therapeutic potential by phosphorylation of the $\mathrm{NF} \times \mathrm{B}$ p 65 subunit. Inhibition of p 65 phosphorylation reduces the expression of inflammatory cytokines, limiting characteristic cell damage of acute inflammation.

\section{Conclusion}

Determination of pro-inflammatory cytokines, MTT assay and DPPH tests revealed that $A$. maculatum leaf extracts possess anti-inflammatory, cytotoxic and antioxidant activities. Therefore, our findings substantiate A. maculatum as a potentially useful herb in alternative medicine against some serious human health problems. Further research on cytotoxicology is required to guarantee herbal drug safety.

\section{Acknowledgments}

The authors are thankful to the Researchers Support \& Services Unit (RSSU) at King Saud University for their technical support.

\section{References}

Abbasi N, Karkondi VR, Asadollahi K, Tahmasebi M, Ghobad A, Taherikalani M, Parisa A (2014) Analgesic effects of Arum maculatum plant extract in rats compared to other routine analgesics. J Med Plants Res 8:1025-1030.

Afifi-Yazar FU, Kasabri V, Abu-Dahab R (2011) Medicinal plants from Jordan in the treatment of cancer: Traditional uses vs. in vitro and in vivo evaluations - Part 1. Planta Med 77:1203-1209.

Agoramoorthy G, Chandrasekaran M, Venkatesalu V, Hsu MJ (2007) Antibacterial and antifungal activities of fatty acid methyl esters of the blind-your-eye mangrove from India. Braz J Microbiol 38:739-742.

Alencar VB, Alencar MNN, Assreuy AMS, Mota, ML, Brito GAC, Aragão KS, Bittencourt FS, Pinto VPT, Debray H, Ribeiro RA, Cavada BS (2005) Pro-inflammatory effect of Arum maculatum lectin and role of resident cells. Int J Biochem Cell Biol 37:1805-1814.

Ali MB, Singh N, Shohael AM, Hahn EJ, Paek KY (2006) Phenolics metabolism and lignin synthesis in root suspension cultures of Panax ginseng in response to copper stress. Plant Sci 171:147-154.

Azab A (2017) Arum: a plant genus with great medicinal potential. Eur Chem Bull 6:59-68.

Banothu V, Neelagiri C, Adepally U, Lingam J, Bommareddy K (2017) Phytochemical screening and evaluation of in vitro antioxidant and antimicrobial activities of the indigenous medicinal plant Albizia odoratissima. Pharm Biol 55:1155-1161.

ÇolaK F, Savaro IF, Ihan S (2009) Antibacterial and antifungal activities of Arum maculatum L. leaves extracts. J Appl Biol Sci 3:13-16.

Cole C, Burgoyne T, Lee A, Stehno-Bittel L, Zaid G (2015) Erratum to: Arum palaestinum with isovanillin, linolenic acid and $\beta$-sitosterol inhibits prostate cancer spheroids and reduces the growth rate of prostate tumors in mice. BMC Complement Altern Med 15:322.

Dewir YH, Chakrabarty D, Lee SH, Hahn EJ, Paek KY (2010) Indirect regeneration of Withania somnifera and comparative analysis of withanolides in in vitro and greenhouse grown plants. Biol Plant 54:357-360.

Dinarello CA (2009) Immunological and inflammatory functions of the interleukin-1 family. Annu Rev Immunol 27:519-550.

Ekor M (2014) The growing use of herbal medicines: Issues relating to adverse reactions and challenges in monitoring safety. Front Pharmacol 4:1-10.

Farid MM, Hussein SR, Ibrahim LF, Desouky MAE, Elsayed AM, Oqlah AAE, Saker MM (2015) Cytotoxic activity and phytochemical analysis of Arum palaestinum Boiss. Asian Pac J Trop Biomed 11:944-947.

Gupta SC, Sundaram C, Reuter S, Aggarwal BB (2010) 
Inhibiting NF- $\propto \mathrm{B}$ activation by small molecules as a therapeutic strategy. Biochim Biophys Acta 1799:775-787.

Harada H, Yamashita U, Kurihara H, Fukushi E, Kawabata J, Kamei Y (2002) Antitumor activity of palmitic acid found as a selective cytotoxic substance in a marine red alga. Anticancer Res 22:2587-2590.

Jiang N, Doseff AI, Grotewold E (2016) Flavones: From biosynthesis to health benefits. Plants (Basel) 5(2):27.

Kadri ZHM, Ibrahim NA, Al-Shmgani HS (2016) Hepatotoxicity evaluation of methanol leaves extract of Arum maculatum. IIOABJ 7:435-440.

Kianinia S, Farjam MH (2018) Chemical and biological evolution of essential oil of Arum maculatum. Iran J Sci Technol Trans Sci 42:395-399.

Kochmarov V, Kozuharova E, Naychov Z Momekov, G Mincheva I (2015) Ethnobotany and ethno-pharmacology of Arum maculatum L. (Araceae) in Bulgaria with an emphasis on its effect against hemorrhoids. Int J Pharm Chem Biol Sci 5:394-402.

Melariri P, Campbell W, Etusim P, Smith P (2012) In vitro and in vivo antimalarial activity of linolenic and linoleic acids and their methyl esters. Adv Stud Biol 4:333-349.

Mimica-Dukic N, Bozin B, Sokovic M, Mihajlovic B, Matavulj M (2003) Antimicrobial and antioxidant activities of three Mentha species essential oils. Planta Med 69:413-419.

Naseef H, Qadadha H, Abu Asfour Y, Israr Sabri I, Al-Rimawi F, Abu-Qatouseh L, Farraj M (2017) Anticancer, antibacterial, and antifungal activities of Arum palaestinum plant extracts. World J Pharm Res 6:31-43.

Nezhadali A, Nabavi M, Akbarpour M (2010) Chemical composition of ethanol/n-hexane extract of the leaf from Tanacetum polycephalum subsp. duderanum as a herbal plant in Iran. Der Pharmacia Sinica 1:147-150.

Nouri MA, Al-Halbosiy MMF, Dheeb BI, Hashim AJ (2015) Cytotoxicity and genotoxicity of gliotoxin on human lymphocytes in vitro. J King Saud Univ-Sci 27:193-197.

O'Shea JJ, Ma A, Lipsky P (2002) Cytokines and autoimmunity. Nat Rev Immunol 2:37-45.

Othman AR, Abdullah N, Ahmad S, Ismail IS, Zakaria MP (2015) Elucidation of in-vitro anti-inflammatory bioactive compounds isolated from Jatropha curcas L. plant root. BMC Complement Altern Med 15:11.
Paek KY, Murthy H, Hahn EJ (2009) Establishment of adventitious root cultures of Echinacea purpurea for the production of caffeic acid derivatives. In Jain SM, Saxena PK, (eds), Protocols for In Vitro Cultures and Secondary Metabolite Analysis of Aromatic and Medicinal Plants. Methods in Molecular Biology (Methods and Protocols), Vol 547, Humana Press, Totowa, NJ.

Pinto MEA, Araújo SG, Morais MI, Sá NP, Lima CM, Rosa CA, Siqueira EP, Johann S, Lima LARS (2017) Antifungal and antioxidant activity of fatty acid methyl esters from vegetable oils. An Acad Bras Cienc 89:1671-1681.

Pipkin PA, Wood DJ, Racaniello VR, Minor PD (1993) Characterization of $\mathrm{L}$ cells expressing the human poliovirus receptor for the specific detection of polioviruses in vitro. J Virol Methods 41:333-340.

Robertson J (2009) Arum maculatum, cuckoopint, lords and ladies. The Poison Garden. http://www.thepoisongarden. co.uk/atoz/arum_maculatum.htm

Safari E, Amiri M, Bahador A, Amiri M, Esmaeili D (2014) The study of antibacterial effects of alcoholic extracts of Arum maculatum, Allium hirtifolium and Teucrium polium against nosocomial resistance bacteria. Int J Curr Microbiol App Sci 3:601-605.

Sathyaprabha G, Kumaravel S, Panneerselvam A (2011) Bioactive compounds identification of Pleurotus platypus and Pleurotus eous by GC-MS. Adv Appl Sci Res 2:51.

Taskeen A, Naeem I, Mubeen H, Mehmood T (2009) Reverse phase high performance liquid chromatographic analysis of flavonoids in two Ficus species. N Y Sci J 2:32-35.

Ulloth JE, Casiano CA, De Leon M (2003) Palmitic and stearic fatty acids induce caspase-dependent and -independent cell death in nerve growth factor differentiated PC12 cells. J Neurochem 84:655-668.

Zaid H, Silbermann M, Ben-Arye E, Saad B (2012) GrecoArab and Islamic herbal-derived anticancer modalities: From tradition to molecular mechanisms. Evid-Based Complement Alternat Med, Article ID 349040. 